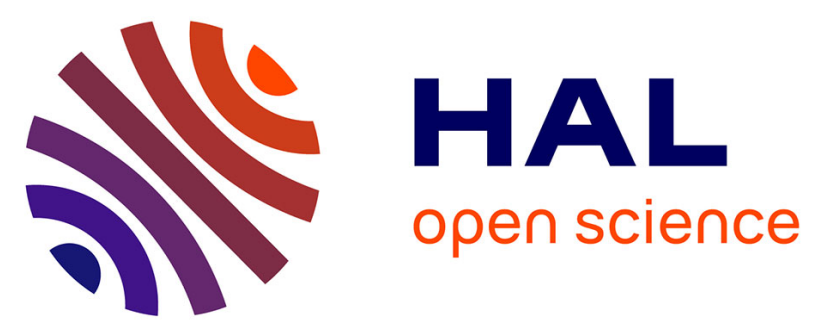

\title{
Combining gas phase electron capture and IRMPD action spectroscopy to probe the electronic structure of a metastable reduced organometallic complex containing a non-innocent ligand
}

\author{
Madanakrishna Katari, Eléonore Payen de La Garanderie, Edith Nicol, \\ Vincent Steinmetz, Guillaume G. van Der Rest, Duncan Carmichael, Gilles
}

Frison

\section{- To cite this version:}

Madanakrishna Katari, Eléonore Payen de La Garanderie, Edith Nicol, Vincent Steinmetz, Guillaume G. van Der Rest, et al.. Combining gas phase electron capture and IRMPD action spectroscopy to probe the electronic structure of a metastable reduced organometallic complex containing a non-innocent ligand. Physical Chemistry Chemical Physics, 2015, 17 (39), pp.25689-25692. 10.1039/C5CP01501D . hal-01158292

\author{
HAL Id: hal-01158292 \\ https://hal.science/hal-01158292
}

Submitted on 31 Dec 2017

HAL is a multi-disciplinary open access archive for the deposit and dissemination of scientific research documents, whether they are published or not. The documents may come from teaching and research institutions in France or abroad, or from public or private research centers.
L'archive ouverte pluridisciplinaire HAL, est destinée au dépôt et à la diffusion de documents scientifiques de niveau recherche, publiés ou non, émanant des établissements d'enseignement et de recherche français ou étrangers, des laboratoires publics ou privés. 


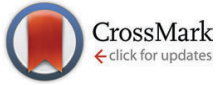

Cite this: Phys. Chem. Chem. Phys., 2015, 17, 25689

Received 13th March 2015, Accepted 29th May 2015

DOI: $10.1039 / c 5 c p 01501 d$

www.rsc.org/pccp

\section{Combining gas phase electron capture and IRMPD action spectroscopy to probe the electronic structure of a metastable reduced organometallic complex containing a non-innocent ligand $\dagger$}

\author{
Madanakrishna Katari, ${ }^{a}$ Eleonore Payen de la Garanderie, ${ }^{a}$ Edith Nicol, ${ }^{a}$ \\ Vincent Steinmetz, ${ }^{b}$ Guillaume van der Rest, ${ }^{b}$ Duncan Carmichael ${ }^{a}$ and \\ Gilles Frison*a
}

Combining electron capture dissociation mass spectrometry and infrared multiple photon dissociation action spectroscopy allows the formation, selection and characterisation of reduced metal complexes containing non-innocent ligands. Zinc complexes containing diazafluorenone ligands have been studied and the localisation of the single electron on the metal atom in the mono-ligated complex has been demonstrated.

Despite the ubiquitous nature of electronic reduction processes, the question of where the reducing electron becomes localized on the recipient molecule often remains unanswered. Addressing this fundamental question is crucial to the understanding of many chemical processes, such as the site(s) of the electron attachment to biological molecules after exposure to ionizing radiation, which leads to cell damage, ${ }^{1}$ or the implication of innocent $v s$. noninnocent ligands in coordination chemistry, ${ }^{2}$ and organometallic ${ }^{2,3}$ or enzymatic catalysis. ${ }^{4}$ Several experimental methods including NMR, EPR, cyclic voltammetry and UV/Vis spectroscopy are available for addressing this issue in solution, but most of them are poorly adapted to the analysis of trace components in complex mixtures, such as catalytic intermediates in ongoing reactions, and often provide only partial information.

Electron-based methods in mass spectrometry (MS) are fragmentation techniques which have shown profound potential for the analysis of peptides and proteins. ${ }^{5}$ They can also provide important information on native protein structure. ${ }^{6}$ Among them, electron capture and transfer dissociation (ECD/ETD) attaches an electron to multiply-charged electrosprayed cations and treats the subsequent fragmentation of the reduced radical cation products. ${ }^{7}$ Obtaining a good electronic description of the product radicals remains an open and challenging issue, ${ }^{8}$ but,

\footnotetext{
${ }^{a}$ Laboratoire de Chimie Moléculaire, Ecole polytechnique and CNRS,

91128 Palaiseau Cedex, France.E-mail: gilles.frison@polytechnique.edu

${ }^{b}$ Laboratoire de Chimie Physique, Université Paris Sud, CNRS, 91405 Orsay, France

$\dagger$ Electronic supplementary information (ESI) available: Experimental and theoretical methods and data. See DOI: 10.1039/c5cp01501d
}

recently, coupling ETD to near-UV photodissociation techniques has allowed the nature of some cation-peptide radical chromophores to be resolved. ${ }^{9}$ Studies of ECD/ETD with transition metal organometallic cations have mostly focused on metal-peptide complexes, ${ }^{10,11}$ although some studies have shown their use for cationized oligosaccharide $\mathrm{e}^{12}$ and phosphocholine ${ }^{13}$ fragmentation, as well as for the generation of reduced cation species in water clusters. ${ }^{14}$ Metal complexes of polyamidoamine dendrimers ${ }^{15}$ and oligonuclear metallo-supramolecular complexes ${ }^{16,17}$ have also been subjected to ECD studies, providing some evidence of electron capture on a bipyridyl ligand. ${ }^{17}$ The capacity of ECD/ETD techniques to generate specifically reduced organometallic radical ions was not explored in these studies. However, a method employing gas phase electron transfer from cesium atoms has been used recently to reduce a dicationic $\mathrm{Ru}$ complex, and the structure of the reduction product was studied by UV-photodissociation. ${ }^{18}$

InfraRed Multiple Photon Dissociation (IRMPD) action spectroscopy has emerged recently as an efficient and generally applicable technique for the analysis of isolated ions through measurement of their IR spectra; ${ }^{19}$ these "action" spectra are generated through on-resonance absorption of multiple IR photons at an active vibrational mode of a mass-selected ion, and take the form of a plot of fragmentation abundance as a function of photon wavelength. Whilst the nature of the multiple photon excitation mechanism can cause the IR action spectra to differ from the calculated linear IR absorption spectra, particularly with respect to relative line intensities, ${ }^{20}$ the resulting experimental spectra are ideally adapted for comparison with DFT-derived computational data, which represent isolated gas phase ions well. They therefore allow the nature of the product species to be verified with precision. IRMPD has been used previously to study interaction of metals with redox-active ligands generated by electrospray ionization. ${ }^{21}$ A combination of ECD and IRMPD techniques has also allowed the structure of an even-electron ECD-generated peptide fragment to be established by IR action spectroscopy. ${ }^{22}$

Herein, we demonstrate the possibility to combine sequentially ECD and IRMPD processes to select organometallic species from 


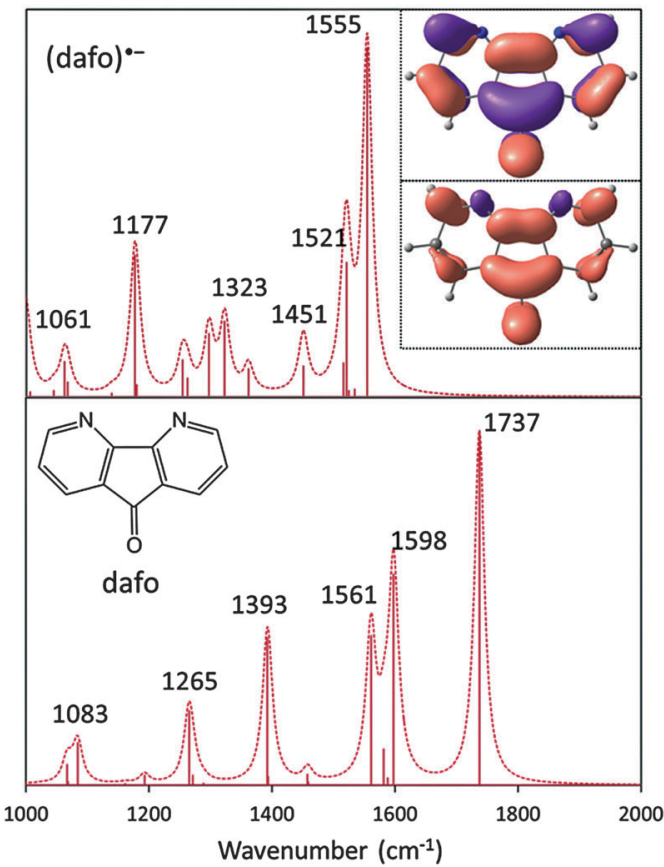

Fig. 1 B3LYP/6-31+G(d,p) calculated IR spectra (scaling factor 0.97) of 4,5-diazafluoren-9-one (bottom) and its reduced form (top). Inset: the SOMO (top) and spin density (bottom) of (dafo) ${ }^{\bullet-}$.

mixtures and characterize the electronic structures of their reduction products in the gas phase. $\mathrm{Zn}$ complexes of 4,5-diazafluoren-9-one (abbreviated here as dafo), a ligand which incorporates two typical functionalities that are widespread in coordination and organometallic chemistry $\left(2,2^{\prime}\right.$-bipyridine and $\left.\mathrm{CO}\right)$, were chosen for the study.

B3LYP/6-31+G(d,p) calculations on both free neutral (dafo), which at this level of calculation has an adiabatic electron affinity of $149 \mathrm{~kJ} \mathrm{~mol}^{-1}$, and its anion radical reduced form (dafo) $)^{\bullet-}$ show that the $\mathrm{C}=\mathrm{O}$ stretching vibration shifts from 1737 to $1555 \mathrm{~cm}^{-1}$ upon accepting an electron (Fig. 1) and confirm that the $\pi$-antibonding nature of the singly occupied molecular orbital (SOMO) delocalizes the unpaired electron well over the whole $\pi$-system. Whilst the bipyridyl unit in the neutral dafo molecule features four well-separated bands around 1580 (mainly CC and CN stretches), 1393 (CH bending), 1265 (CC stretches and $\mathrm{CH}$ bending) and 1083 ( $\mathrm{CH}$ bending) $\mathrm{cm}^{-1}$, a more complex signature including many different bands (mixed CC and CN stretches, and $\mathrm{CH}$ bending) between 1000 and $1521 \mathrm{~cm}^{-1}$ appears for the reduced radical anion (dafo) ${ }^{--}$(see the $\mathrm{ESI}^{\dagger} \dagger$ for a complete description of the calculated bands).

Subjecting a simple $3: 1$ mixture of dafo and $\mathrm{Zn}\left(\mathrm{BF}_{4}\right)_{2}$ in a $1: 2$ water/acetonitrile solution to electrospray ionization generates, inter alia, the gas-phase $\left[\mathrm{Zn}(\mathrm{dafo})_{3}\right]^{2+}$ complex $(\mathrm{m} / z$ 305). This ion was mass-selected and irradiated with monochromated IR photons. When these were on resonance, multiple photon absorption induced dissociation of the ion, with the loss of a neutral dafo ligand to yield a product ion at $m / z 214$ (see MS spectrum in the ESI $\dagger$ ). IR action spectroscopy of $\left[\mathrm{Zn}(\mathrm{dafo})_{3}\right]^{2+}$ was performed in the $1000-2000 \mathrm{~cm}^{-1}$ region (Fig. 2) and five bands, centered at 1090, 1229, 1407, 1569 and

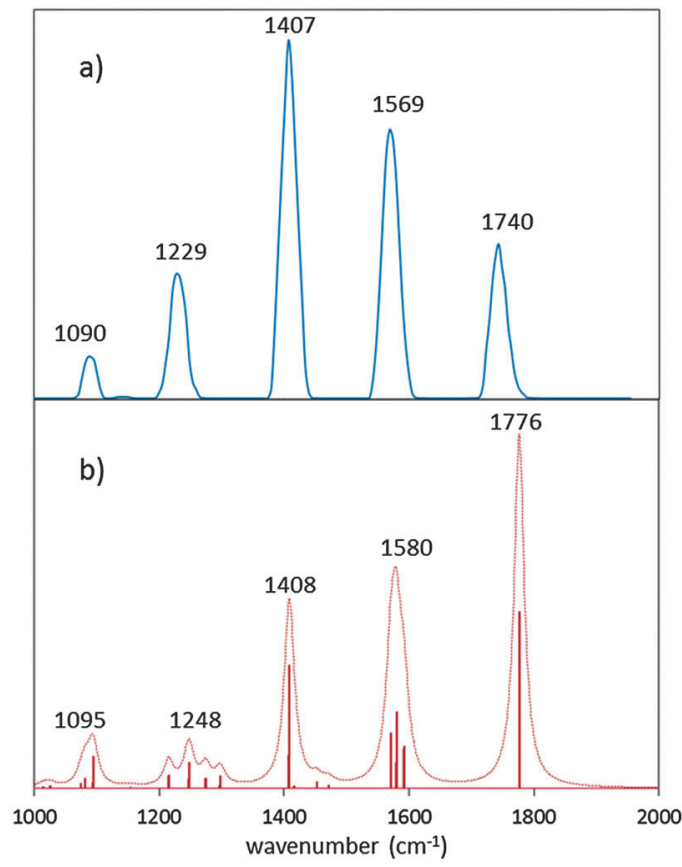

Fig. 2 Experimental IR action spectrum (a) and calculated IR absorption spectrum at the B3LYP/6-31+G(d,p) level (scaling factor 0.97) (b) of $\left[\mathrm{Zn}\left(\text { dafo }_{3}\right]^{2+}\right.$

$1740 \mathrm{~cm}^{-1}$ are revealed in the experimental spectrum. These lie close those calculated at the DFT level for the octahedral $\left[\mathrm{Zn}(\mathrm{dafo})_{3}\right]^{2+}$ complex wherein all three ligands are equivalent; the $\mathrm{C}=\mathrm{O}$ stretching frequency of $1740 \mathrm{~cm}^{-1}\left(\mathrm{DFT}: 1776 \mathrm{~cm}^{-1}\right)$ is close to the calculated value for the free ligand dafo $\left(1737 \mathrm{~cm}^{-1}\right)$, whilst the other bands (CC and $\mathrm{CN}$ stretching and $\mathrm{CH}$ bending) also overlap nicely with those of the free ligand. Coordination to the zinc(II) center therefore has minimal influence on the ligand spectroscopic signature.

Application of ECD to effect reduction of the $\left[\mathrm{Zn}(\mathrm{dafo})_{3}\right]^{2+}$ dication generated the spectrum given in Fig. 3. One unique product having an $\mathrm{m} / \mathrm{z}$ of 246 is observed, so that gas phase monoelectron capture is associated with the release of two neutral dafo ligands, and the product is $[\mathrm{Zn}(\mathrm{dafo})]^{\circ+}$. This fragmentation is

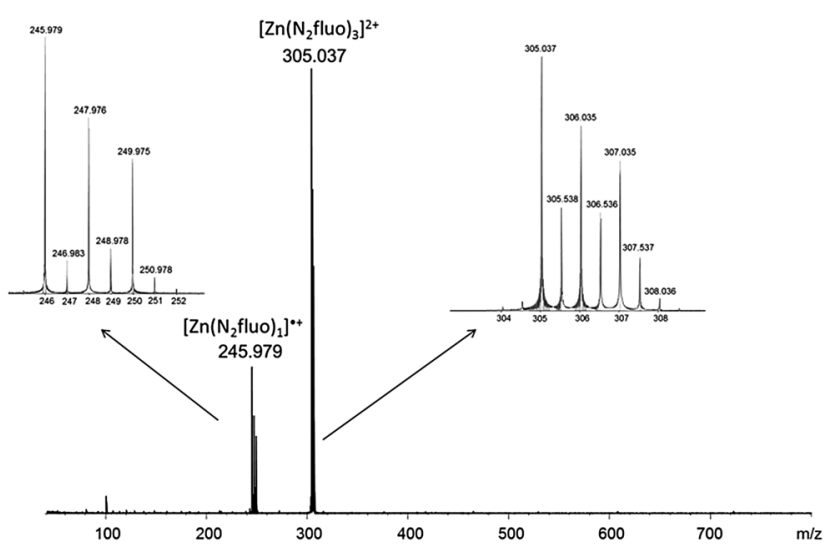

Fig. 3 ECD mass spectrum of $\left[\mathrm{Zn}\left(\text { dafo }_{3}\right]^{2+}\right.$. The peak at $m / z 101.679$ is the third harmonic of the parent ion. 
consistent with $\mathrm{B} 3 \mathrm{LYP} / 6-31+\mathrm{G}(\mathrm{d}, \mathrm{p})$ calculations that predict (a) a vertical electron affinity for $\left[\mathrm{Zn}(\text { dafo })_{3}\right]^{2+}$ of $717 \mathrm{~kJ} \mathrm{~mol}^{-1}$ and (b) that the dissociation of the two neutral ligands is endothermic by $641 \mathrm{~kJ} \mathrm{~mol}^{-1}$.

$\mathrm{N}$-donor chelating ligands of the bipy family are important because of their ability to accept an electron to form bipyridyl radical anions, in $\left[\mathrm{Ru}(\text { bipy })_{3}\right]^{\bullet+}$ and related complexes. ${ }^{23}$ This is well known in solution, where the solvent can stabilize the ligand as a radical anion, but has also been demonstrated recently for gas phase metal complexes. ${ }^{17,18}$ Equally, $\mathrm{Zn}^{2+}$ is apt for the capture of an incoming electron in $\mathrm{Zn}$-peptide systems. ${ }^{10}$ The generation of the $[\mathrm{Zn}(\text { dafo })]^{++}$radical above allows its electronic structure and the electron localization on the two potential ( $\mathrm{Zn}$ and dafo) sites to be probed experimentally through IR action spectroscopy.

The observation of one intense band at $1415 \mathrm{~cm}^{-1}$ and four low intensity bands at $1104,1245,1581$ and $1756 \mathrm{~cm}^{-1}$ in the IR action spectrum of [Zn(dafo) $]^{++}$(Fig. 4), along with their similarity to the IR action spectrum of $\left[\mathrm{Zn}(\text { dafo })_{3}\right]^{2+}$, indicate that the dafo ligand in $[\mathrm{Zn}(\text { dafo })]^{{ }^{+}}$does not take the electron: both the $\mathrm{C}=\mathrm{O}$ stretching mode and the delocalized $\mathrm{CC}$ and $\mathrm{CN}$ stretching and $\mathrm{CH}$ bending modes remain unperturbed, so it is the zinc center that is reduced. This is confirmed by DFT calculations, which give an electronic ground state having the single electron located on the metal center and provide a calculated IR spectrum for $\left[\left(\mathrm{Zn}^{\bullet+}\right)(\right.$ dafo $\left.)\right]$ that matches the experimental IR action spectrum well (Fig. 4).

The fragment that is observed at $m / z 182$ when $[\mathrm{Zn}(\text { dafo })]^{{ }^{+}}$ $(\mathrm{m} / \mathrm{z} 246)$ is photon irradiated at appropriate resonance frequencies (Fig. 5) results from the collapse of $[\mathrm{Zn}(\text { dafo })]^{\bullet+}$ through loss of neutral $\mathrm{Zn}(0)$ to form the free ligand radical cation (dafo) ${ }^{\bullet+}$; a similar fragmentation process has been observed recently in collision-induced dissociation of $[\mathrm{Zn}(\text { bipy })]^{\bullet+}$ complex. $^{24} \mathrm{~B} 3 \mathrm{LYP} /$ $6-31+G(d, p)$ calculations indicate that this fragmentation channel

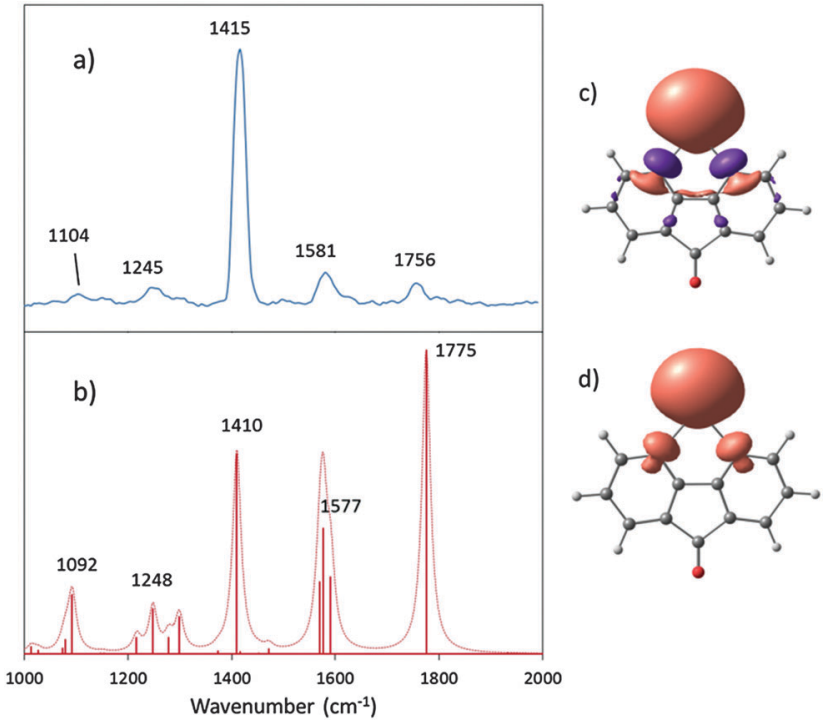

Fig. 4 Experimental IR action spectrum of $[\mathrm{Zn}(\text { dafo })]^{\bullet+}$ (a) and its calculated IR absorption spectrum (b), SOMO (c) and spin density (d) in the ground state at the B3LYP/6-31+G(d,p) level (scaling factor 0.97). Note the intensity differences between the DFT-predicted classical IR spectrum and the IRMPD generated experimental spectrum.

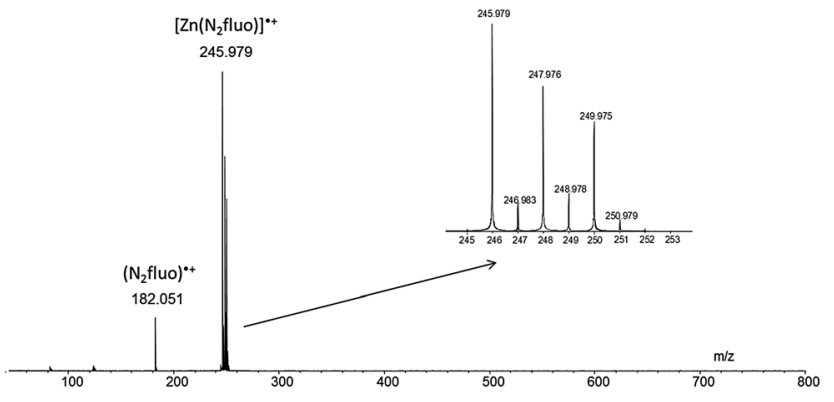

Fig. 5 IRMPD mass spectrum obtained after mass selection of [Zn(dafo) $]^{\bullet+}$ $(\mathrm{m} / \mathrm{z} 246)$ and irradiation on resonance at $1415 \mathrm{~cm}^{-1}$.

(i) is more favorable by $80 \mathrm{~kJ} \mathrm{~mol}^{-1}$ than the formation of $\mathrm{Zn}^{\bullet+}$ and neutral dafo; and (ii) is significantly more endothermic $\left(237 \mathrm{~kJ} \mathrm{~mol}^{-1}\right)$ than the loss of one dafo ligand from $\left[\mathrm{Zn}(\text { dafo })_{3}\right]^{2+}$ that was observed above (157 $\left.\mathrm{kJ} \mathrm{mol}^{-1}\right)$, and this explains the relatively noisy IR action spectrum, despite prolonged IR irradiation $(2 \mathrm{~s})$ compared to that used for $\left[\mathrm{Zn}(\text { dafo })_{3}\right]^{2+}(0.45 \mathrm{~s})$. Both the localization of the incoming electron in the $[\mathrm{Zn}(\mathrm{dafo})]^{{ }^{+}}$radical cation and its fragmentation pathway are therefore established.

The experiments demonstrate that a desired organometallic complex can be selected by electrospray MS from a mixture and then mono-reduced in the gas phase, where its vibrational spectra can be obtained. This provides an IR spectroscopic signature of a reduced metal-ligand ensemble which can then be compared either (a) with spectra observed in non-reduced systems or (b) with DFT computational results. Further, coupling ECD and IR action spectroscopy constitutes an approach that is likely to be particularly advantageous when studies of highly reactive radical complexes that are unstable in solution are required. Likewise, the means to generate simple monoligated metal centers for study, that this methodology provides, obviously constitutes a particularly desirable simplification for interpreting any $\mathbf{M}-\mathbf{L}$ interactions that may be essential to catalytic processes. Finally, the gas phase signature of these species has been shown to reveal intimate details of the localization of the single electron within the complex. Comparison with solvated ions should allow the influence of solvent molecules or counter ions in the electronic structure of reduced species to be identified and optimised. ${ }^{25}$

\section{Acknowledgements}

This work was performed using HPC resources from GENCI-CINES (Grant 2014-x086894). MK and EPdlG thank the Ecole polytechnique for stipends. Financial support from the National FT-ICR network (FR 3624 CNRS) for conducting the research is gratefully acknowledged. We thank Joëlle Char for preliminary work on this project.

\section{Notes and references}

1 E. Alizadeh and L. Sanche, Chem. Rev., 2012, 112, 5578-5602.

2 A. I. O. Suarez, V. Lyaskovskyy, J. N. H. Reek, J. I. van der Vlugt and B. de Bruin, Angew. Chem., Int. Ed., 2013, 52, 12510-12529; T. Büttner, J. Geier, G. Frison, J. Harmer, 
C. Calle, A. Schweiger, H. Schönberg and H. Grützmacher, Science, 2005, 307, 235-238.

3 P. J. Chirik and K. Wieghardt, Science, 2010, 327, 794-795; S. Blanchard, E. Derat, M. Desage-El Murr, L. Fensterbank, M. Malacria and V. Mouriès-Mansuy, Eur. J. Inorg. Chem., 2012, 376-389; O. R. Luca and R. H. Crabtree, Chem. Soc. Rev., 2013, 42, 1440-1459.

4 J. Stubbe and and W. A. van der Donk, Chem. Rev., 1998, 98, 705-762; J. W. Whittaker, Chem. Rev., 2003, 103, 2347-2363.

5 R. A. Zubarev, Mass Spectrom. Rev., 2003, 22, 57-77; H. J. Cooper, K. Hakansson and A. G. Marshall, Mass Spectrom. Rev., 2005, 24, 201-222; L. M. Mikesh, B. Ueberheide, A. Chi, J. J. Coon, J. E. P. Syka, J. Shabanowitz and D. F. Hunt, Biochim. Biophys. Acta, 2006, 1764, 1811-1822; K. O. Zhurov, L. Fornelli, M. D. Wodrich, Ü. A. Laskay and Y. O. Tsybin, Chem. Soc. Rev., 2013, 42, 5014-5030.

6 K. Breuker and F. W. McLafferty, Angew. Chem., Int. Ed., 2003, 42, 4900-4904; S. R. Harvey, M. Porrini, A. Konijnenberg, D. J. Clarke, R. C. Tyler, P. R. R. Langridge-Smith, C. E. MacPhee, B. F. Volkman and P. E. Barran, J. Phys. Chem. B, 2014, 118, 12348-12359.

7 J. Simons, Chem. Phys. Lett., 2010, 484, 81-95; F. Turecek and R. R. Julian, Chem. Rev., 2013, 113, 6691-6733.

8 A. I. Gilson, G. van der Rest, J. Chamot-Rooke, W. Kurlancheek, M. Head-Gordon, D. Jacquemin and G. Frison, J. Phys. Chem. Lett., 2011, 2, 1426-1431; V. Riffet, D. Jacquemin, E. Cauët and G. Frison, J. Chem. Theory Comput., 2014, 10, 3308-3318.

9 C. J. Shaffer, A. Marek, R. Pepin, K. Slovakova and F. Turecek, J. Mass Spectrom., 2015, 50, 470-475; H. T. H. Nguyen, C. J. Shaffer and F. Turecek, J. Phys. Chem. B, 2015, 119, 3948-3961.

10 X. Chen, W. Y. K. Chan, P. S. Wong, H. S. Yeung and T. W. D. Chan, J. Am. Soc. Mass Spectrom., 2011, 22, 233-244.

11 T. G. Flick, W. A. Donald and E. R. Williams, J. Am. Soc. Mass Spectrom., 2013, 24, 193-201.

12 J. T. Adamson and K. Hakansson, Anal. Chem., 2007, 79, 2901-2910; L. Han and C. E. Costello, J. Am. Soc. Mass Spectrom., 2011, 22, 997-1013.

13 P. F. James, M. A. Perugini and R. A. J. O'Hair, J. Am. Soc. Mass Spectrom., 2008, 19, 978-986.
14 W. A. Donald, R. D. Leib, J. T. O’Brien, A. I. S. Holm and E. R. Williams, Proc. Natl. Acad. Sci. U. S. A., 2008, 105, 18102-18107; W. A. Donald, R. D. Leib, J. T. O'Brien and E. R. Williams, Chem. - Eur. J., 2009, 15, 5926-5934; W. A. Donald, M. Demireva, R. D. Leib, M. J. Aiken and E. R. Williams, J. Am. Chem. Soc., 2010, 132, 4633-4640.

15 M. A. Kaczorowska and H. J. Cooper, J. Am. Soc. Mass Spectrom., 2009, 20, 674-681.

16 M. A. Kaczorowska, A. C. G. Hotze, M. J. Hannon and H. J. Cooper, J. Am. Soc. Mass Spectrom., 2010, 21, 300-309; C. Gütz, R. Hovorka, N. Struch, J. Bunzen, G. Meyer-Eppler, Z. W. Qu, S. Grimme, F. Topic, K. Rissanen, M. Cetina, M. Engeser and A. Lützen, J. Am. Chem. Soc., 2014, 136, 11830-11838.

17 R. Hovorka, M. Engeser and A. Lützen, Int. J. Mass Spectrom., 2013, 354-355, 152-158.

18 C. S. Byskov, J. M. Weberc and S. Brondsted Nielsen, Phys. Chem. Chem. Phys., 2015, 17, 5561-5564.

19 T. D. Fridgen, Mass Spectrom. Rev., 2009, 28, 586-607; J. R. Eyler, Mass Spectrom. Rev., 2009, 28, 448-467; N. C. Polfer and J. Oomens, Mass Spectrom. Rev., 2009, 28, 468-494; J. Roithova, Chem. Soc. Rev., 2012, 41, 547-559.

20 N. C. Polfer, Chem. Soc. Rev., 2011, 40, 2211-2221.

21 P. Milko, J. Roithova, N. Tsierkezos and D. Schröder, J. Am. Chem. Soc., 2008, 130, 7186-7187; P. Milko, J. Roithova, D. Schröder, J. Lemaire, H. Schwarz and M. C. Holthausen, Chem. - Eur. J., 2008, 14, 4318-4327; P. Milko and J. Roithova, Inorg. Chem., 2009, 48, 11734-11742; L. Duchackova, V. Steinmetz, J. Lemaire and J. Roithova, Inorg. Chem., 2010, 49, 8897-8903; L. Duchackova, J. Roithova, P. Milko, J. Zabka, N. Tsierkezos and D. Schröder, Inorg. Chem., 2011, 50, 771-782.

22 G. Frison, G. van der Rest, F. Turecek, T. Besson, J. Lemaire, P. Maitre and J. Chamot-Rooke, J. Am. Chem. Soc., 2008, 130, 14916-14917.

23 B. Noble and R. D. Peacock, Inorg. Chem., 1996, 35, 1616-1620.

24 N. S. Rannulu and M. T. Rodgers, J. Phys. Chem. A, 2012, 116, 1319-1332.

25 J. Gu, J. Leszczynskic and H. F. Schaefer III, Chem. Rev., 2012, 112, 5603-5640. 